\title{
Governance Challenges in Global Health
}

\section{Citation}

Frenk, Julio, and Suerie Moon. 2013. "Governance Challenges in Global Health." New England Journal of Medicine 368 (10) (March 7): 936-942. doi:10.1056/nejmra1109339.

\section{Published Version}

doi:10.1056/NEJMra1109339

\section{Permanent link}

http://nrs.harvard.edu/urn-3:HUL.InstRepos:37260722

\section{Terms of Use}

This article was downloaded from Harvard University's DASH repository, and is made available under the terms and conditions applicable to Other Posted Material, as set forth at http:// nrs.harvard.edu/urn-3:HUL.InstRepos:dash.current.terms-of-use\#LAA

\section{Share Your Story}

The Harvard community has made this article openly available.

Please share how this access benefits you. Submit a story.

\section{Accessibility}


GLOBAL HEALTH

\title{
Governance Challenges in Global Health
}

\author{
Julio Frenk, M.D., M.P.H., Ph.D., and Suerie Moon, M.P.A., Ph.D.
}

\begin{abstract}
From the Harvard School of Public Health, Boston; and the John F. Kennedy School of Government and the Forum on Global Governance for Health, Harvard Global Health Institute - both in Cambridge, MA. Address reprint requests to Dr. Frenk at the Harvard School of Public Health, Kresge 1005, 677 Huntington Ave., Boston, MA 02115, or at deansoff@ hsph.harvard.edu.
\end{abstract}

N Engl J Med 2013;368:936-42. DOI: 10.1056/NEJMral109339

Copyright (C) 2013 Massachusetts Medical Society.

\footnotetext{
G
} LOBAL HEALTH IS AT THE THRESHOLD OF A NEW ERA. FEW TIMES IN HIStory has the world faced challenges as complex as those now posed by a trio of threats: first, the unfinished agenda of infections, undernutrition, and reproductive health problems; second, the rising global burden of noncommunicable diseases and their associated risk factors, such as smoking and obesity; and third, the challenges arising from globalization itself, such as the health effects of climate change and trade policies, which demand engagement outside the traditional health sector. ${ }^{1}$ These threats are evolving within a multifaceted and dynamic global context characterized by great diversity among societies in norms, values, and interests, as well as by large inequalities in the distribution of health risks and the resources to address them.

A robust response to this complex picture requires improved governance of health systems - certainly at the national level but also at a worldwide level in what could be thought of as the "global health system." However, the concept of governance is still poorly understood despite its growing visibility in current debates about global health. In this article, we define and discuss the importance of good global governance for health, outline major challenges to such governance, and describe the necessary functions of a global health system.

UNDERSTANDING GLOBAL HEALTH AND GOVERNANCE

There are many working definitions of global health. Some emphasize certain types of health problems (e.g., communicable diseases), whereas others emphasize certain populations of interest (e.g., the poor), focus on a geographic area (e.g., the Global South), or have a specific mission (e.g., equity). Global health encompasses all these dimensions, but each of them in isolation offers only a partial perspective. In our view, global health should be defined by two key elements: its level of analysis, which involves the entire population of the world, and the relationships of interdependence that bind together the units of social organization that make up the global population (e.g., nation states, private organizations, ethnic groups, and civil society movements).

When thinking about health in populations, we must analyze two essential dimensions: health conditions (e.g., diseases and risk factors) and the way in which a society responds to those conditions. This framework can be applied at both the national level and the global level. Faced with a set of health conditions, a country articulates a response through its national health system. At the global level, the key concept in understanding the pattern of health conditions is the international transfer of health risks - that is, the way in which the movement of people, products, resources, and lifestyles across borders can contribute to the spread of disease. ${ }^{2}$ Globalization has intensified cross-border health threats, ${ }^{3}$ leading to a situation of health interdependence - the notion that no nation or organization is able to 
address single-handedly the health threats it faces but instead must rely to some degree on others to mount an effective response. ${ }^{4}$ The organized social response to health conditions at the global level is what we call the global health system, and the way in which the system is managed is what we refer to as governance.

The notion of governance goes beyond the formal mechanisms of government and refers to the totality of ways in which a society organizes and collectively manages its affairs. ${ }^{5}$ Global governance is the extension of this notion to the world as a whole. ${ }^{6-8}$ It can refer to the formal decision-making processes of the United Nations Security Council, for example, or to less formal ways of influencing behavior, such as voluntary codes of conduct for multinational corporations. It includes the myriad processes that shape the way we collectively address issues of global significance, such as financial stability, environmental sustainability, peace and security, human rights, and public health. ${ }^{8}$

Global governance is distinct from national governance in one critical respect: there is no government at the global level. Populations are organized into sovereign nation states, but there is no hierarchical political authority, or world government, that has jurisdiction over these nation states. Traditional instruments for mobilizing collective action at the national level - such as taxation, routine law enforcement, and democratic decision-making procedures - are mostly absent at the global level. As a result, societies face enduring challenges to agree on and enforce rules, coordinate action, achieve policy coherence, and ensure accountability. In the aftermath of World War II, governments created multilateral institutions, such as the United Nations system, to help coordinate actions for shared social objectives, including public health. Thus was born, in 1948, the World Health Organization (WHO), the public health authority within the United Nations. The WHO is now governed by 194 member states and is charged with organizing international responses to shared health challenges. However, there is widespread consensus that the current institutional architecture, now more than 60 years old, is unable to respond effectively to contemporary global health threats. Today, the WHO stands on a crowded stage; though once seen as the sole authority on global health, the WHO is now surrounded by many diverse actors.
THE GLOBAL HEALTH SYSTEM:

THE NEW REALITY OF PLURALISM

The global health system is the group of actors whose primary intent is to improve health, along with the rules and norms governing their interactions. ${ }^{9}$ At the core of the system are national governments, with their specialized health ministries, departments, or agencies, and, in the case of donor nations, the health programs of their respective bilateral development cooperation agencies (Table 1). National governments coordinate their responses to common health challenges through a variety of mechanisms. The WHO is the only actor in the global health system that is built on the universal membership of all recognized sovereign nation states (though it is often identified only with its secretariat), and it therefore is central to the system. Also important to the system are other United Nations and multilateral agencies that have health components (e.g., the United Nations Children's Fund [UNICEF], the World Bank, and the regional development banks), along with a diverse set of civil society organizations, multinational corporations, foundations, and academic institutions. This pluralistic landscape has been enriched by a set of innovative and influential hybrid organizations, such as the GAVI Alliance (formerly the Global Alliance for Vaccines and Immunization), UNITAID (which works to improve the functioning of global markets for commodities for the acquired immunodeficiency syndrome [AIDS], tuberculosis, and malaria), and the Global Fund to Fight AIDS, Tuberculosis, and Malaria, which are governed by representatives both from within and from outside national governments. During the past decade, there has been a population explosion in the system, and there are now more than 175 initiatives, funds, agencies, and donors. ${ }^{30}$

To make matters even more complex, health is increasingly influenced by decisions that are made in other global policymaking arenas, such as those governing international trade, migration, and the environment (see interactive graphic at NEJM .org). ${ }^{31-33}$ Actors in these arenas influence health, even though that is not their primary intent. A major example of such an institution is the World Trade Organization, which has profoundly shaped domestic and global intellectual property rules relating to pharmaceuticals, among other healthrelated trade issues. These policymaking institu-

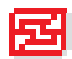

An interactive graphic depicting the global health system is available at NEJM.org 
Table 1. Primary Types of Actors in the Global Health System, with Examples.

Type of Actor and Examples

Annual Expenditures*

millions of U.S. dollars (year)

National governments

Ministries of health $†$

ND

Ministries of foreign affairst

ND

Public research funders

U.S. National Institutes of Health

$30,860(2010)^{10}$

Bilateral development cooperation agencies

U.S. Agency for International Development and U.S. Department of State (global health and child survival)

U.K. Department for International Development (global health)

$7,779(2010)^{11}$

Norwegian Agency for Development Cooperation (health and social services)

$585(2011)^{12}$

$329(2010)^{13}$

United Nations system

World Health Organization

$2,000(2010)^{14}$

United Nations Children's Fund

$3,653(2010)^{15}$

United Nations Population Fund

$801(2010)^{16}$

Joint United Nations Program on HIV/AIDS

$242(2009)^{17}$

\section{Multilateral development banks}

World Bank (health and other social services lending)

$6,707(2011)^{18}$

Regional development banks

$\mathrm{NA}$

Global health initiatives (hybrids)

Global Fund to Fight AIDS, Tuberculosis, and Malaria

$3,475(2010)^{19}$

GAVI Alliance

$934(2010)^{20}$

UNITAID

$269(2010)^{21}$

Philanthropic organizations

Bill and Melinda Gates Foundation (global health)

$1,485(2010)^{22}$

Rockefeller Foundation (all sectors)

$173(2009)^{23}$

Wellcome Trust

$1,114(2010)^{24}$

Global civil society organizations and nongovernmental organizations

Doctors without Borders (Médecins sans Frontières)

$1,080(2010)^{25}$

Oxfam International

$1,210(2010)^{26}$

CARE International

$805(2010)^{27}$

Private industry

Pharmaceutical companies (global market)

$856,000(2010)^{28}$

Professional associations

World Medical Association

NA

Academic institutions

Postsecondary educational institutions for health professionals

$100,000^{29} \div$

* All conversions of currency to U.S. dollars were based on average exchange rates for the year cited. NA denotes not available, and ND no data.

$\dagger$ Ministries of health and ministries of foreign affairs are the parts of national governments that are likely to be particularly relevant for the global health system. Expenditures are not included, since the relevant data are generally not disaggregated or reported in this way.

$\downarrow$ This value represents a worldwide estimate.

The New England Journal of Medicine

Downloaded from nejm.org on July 14, 2018. For personal use only. No other uses without permission.

Copyright (c) 2013 Massachusetts Medical Society. All rights reserved. 
tions are not part of the global health system; instead, they represent critical policy arenas in which global health actors must learn to exert influence. The importance of these arenas is the reason why we prefer the term "global governance for health," rather than the more restrictive notion of "global health governance," which tends to focus only on entities specializing in health matters.

The challenge of achieving good governance among the diverse group of actors (Table 1 ) has drawn increased political attention. ${ }^{34-38}$ Thus far, however, too little attention has been given to the problem of protecting and promoting health in governance processes outside the global health system. ${ }^{39}$ "Good" global governance for health should exhibit at least the following key traits: effectiveness, equity, and efficiency in achieving outcomes, as well as credibility and legitimacy in decision-making processes. However, the achievement of these goals is hampered by three persistent governance challenges that are embedded in the structure of the global system: the sovereignty challenge, the sectoral challenge, and the accountability challenge.

MAJOR GOVERNANCE CHALLENGES FOR GLOBAL HEALTH

\section{THE SOVEREIGNTY CHALLENGE}

In a world of sovereign nation states, health continues to be primarily a national responsibility; however, the intensified transfer of health risks across borders means that the determinants of health and the means to fulfill that responsibility lie increasingly beyond the control of any one nation state. ${ }^{40}$ In the absence of a world government, there is an inherent tension between the reality of national sovereignty and the imperative of international collective action to properly manage interdependence. Sovereignty can confound attempts at transnational coordination, rulemaking, and adjudication. These tasks become even more difficult given the highly unequal distribution of health risks and resources, the opposing interests of various actors, the diversity of cultures and histories, and the rapidly changing distribution of power among countries in the global system. In a context of deepening health interdependence, it becomes more urgent and yet more difficult for countries to agree on their respective responsibilities, obligations, rights, and duties, hampering effective responses to common health threats.

\section{THE SECTORAL CHALLENGE}

Global health is increasingly the product of cross-sector interdependence - that is, the outcome of policymaking processes across multiple sectors. ${ }^{41,42}$ However, global health actors today are largely unequipped to ensure that health concerns are adequately taken into account in crucial policymaking arenas such as trade, investment, security, the environment, migration, and education.

\section{THE ACCOUNTABILITY CHALLENGE}

The formal institutions of global governance, such as the United Nations system, are built on the principle that governments of nation states are the primary decision makers and representatives of their population's interests at the international level. However, new forms of social organization are challenging the primacy of the nation state in the global arena through what David Fidler calls the "unstructured plurality" of nonstate actors. ${ }^{36}$ For example, civil society networks, experts, foundations, multinational corporations, and journalists all wield power in processes of global governance independently of their home-country governments. Two types of accountability problems arise in the current context. The first relates to the legitimacy of intergovernmental organizations, which are formally accountable to the governments of member states rather than directly to the people whose universal rights they are supposed to uphold. This situation too often leads to a "democratic deficit" in the way the organizations operate. This is particularly problematic when people consider their own national governance processes to be illegitimate, such as when governments restrict democratic participation, fail to represent marginalized groups, or otherwise violate the human rights of their own populations.

The second type of problem is the lack of clear mechanisms for the accountability of nonstate actors. Although the lines of accountability that stretch from intergovernmental organizations to member states to populations are clear, albeit problematic, the mechanisms for demanding that nonstate actors operating in the global arena - corporations, civil society organizations, foundations, experts, and journalists - be accountable for the global effects of their actions are relatively vague, at best. We lack effective institutions to govern the many powerful nonstate actors that influence global health today. 


\begin{tabular}{|c|c|}
\hline Function & Subfunctions \\
\hline Production of global public goods & $\begin{array}{l}\text { Research and development, standards } \\
\text { and guidelines, and comparative } \\
\text { evidence and analyses }\end{array}$ \\
\hline $\begin{array}{l}\text { Management of externalities across } \\
\text { countries }\end{array}$ & $\begin{array}{l}\text { Surveillance and information sharing } \\
\text { and coordination for preparedness } \\
\text { and response }\end{array}$ \\
\hline Mobilization of global solidarity & $\begin{array}{l}\text { Development financing, technical coop- } \\
\text { eration, humanitarian assistance, } \\
\text { and agency for the dispossessed }\end{array}$ \\
\hline Stewardship & $\begin{array}{l}\text { Convening for negotiation and consensus } \\
\text { building, priority setting, rule setting, } \\
\text { evaluation for mutual accountability, } \\
\text { and cross-sector health advocacy }\end{array}$ \\
\hline
\end{tabular}

FOUR FUNCTIONS OF THE GLOBAL

HEALTH SYSTEM

These three governance challenges impede the performance of the global health system, which must carry out a number of functions to achieve common goals. Here we describe four key functions of the global health system and briefly illustrate the ways in which governance challenges can hinder attempts to carry them out (Table 2).

The first function is the production of global public goods, especially knowledge-related goods. ${ }^{43}$ Examples include tools for international standardization (e.g., the International Classification of Diseases), guidelines regarding best practice (e.g., the WHO Model List of Essential Medicines), research and development of new technologies, ${ }^{44}$ and comparative analyses and evaluation of policies and programs with respect to design and implementation. The production of global public goods requires sufficient and sustainable resources, which can be difficult to generate when sovereign states can benefit from investments made by others without contributing themselves (a situation known as free-riding). ${ }^{45}$ Effective governance arrangements among sovereign states, such as core funding for the WHO or binding legal instruments, may be needed to overcome the free-rider problem and ensure sufficient production of global public goods. ${ }^{46}$

The second function is the management of externalities to prevent or mitigate the negative health effects that situations or decisions originating in one country might have on others. It involves the deployment of instruments (e.g., surveillance systems, coordination mechanisms, and information-sharing channels) that are es- sential for controlling the international transfer of risks and ensuring a timely response to threats that spread across borders (e.g., drug resistance, pandemics, environmental pollutants, and marketing of unhealthful products such as tobacco). However, sovereignty and weak accountability mechanisms make managing externalities difficult. For example, a government may delay the disclosure of a disease outbreak for fear of economic repercussions or it could refuse to tighten regulations on an industry that pollutes the air or water flowing into a neighboring country. In both cases, there is no supranational body with authority to stop such a government from generating negative externalities.

The third function is the mobilization of global solidarity, which has been the predominant focus of traditional approaches to global health, mostly through the provision of aid. (We use the term "solidarity" in the context of classical sociological theory, rather than of any particular political ideology. ${ }^{47}$ ) The need for this function arises from the unequal distribution of both health problems and the resources to address them. The broad concept of solidarity encompasses four major subfunctions: development financing; technical cooperation, including capacity strengthening; humanitarian assistance to provide relief during natural or manmade disasters; and agency for the dispossessed, ${ }^{40}$ in which the global community takes responsibility for protecting the rights of specific groups (e.g., displaced populations or minorities) when their own governments are not willing or able to do so. There is a clear case for global solidarity when the health system of a country is chronically incapable of addressing the needs of its population or when it is acutely overwhelmed by a crisis. However, carrying out this function can be difficult in a system of sovereign states with few accountability mechanisms. For example, if a state objects when the global community takes an interest in its marginalized groups or if it chooses not to contribute to international humanitarian relief efforts, there are few options to make that state do otherwise. Even if a state commits to providing development assistance, there are few mechanisms for accountability if it reneges.

The fourth function is stewardship, which provides overall strategic direction to the global health system so that all other functions can be performed adequately. ${ }^{48}$ Stewardship includes the following subfunctions: convening for negotiation and consensus building (e.g., regarding policy 
frameworks such as Health for All through primary health care), setting priorities (e.g., among disease categories or intervention strategies), setting rules to manage the many dimensions of health interdependence (e.g., through the Framework Convention on Tobacco Control), evaluating actors and actions to ensure mutual accountability, and advocating for health across sectors. This last subfunction requires health actors to manage the sectoral challenge by learning to advocate effectively for health considerations in the other policy arenas that influence global health. Stewardship requires trusted leadership, credible and legitimate processes, and sufficient political space to protect public health in the face of powerful competing interests. Yet all these factors can be undermined when mechanisms for accountability are weak or when sovereign states put narrowly conceived self-interests before global health.

\section{IMPLICATIONS FOR POLICY}

Strengthening the global health system will require managing persistent governance challenges to ensure that key functions are performed. It will also require increased clarity regarding which actors should carry out which functions to avoid a situation in which there is inefficient overlap on some functions while others are overlooked. Consensus regarding the core functions of each major actor should determine institutional arrangements: form should follow function. This endeavor has become even more urgent given the slowdown in funding for global health. ${ }^{49}$

In current debates about WHO reform, attention should be paid to the functions this institution performs within the larger global health system and the governance challenges that must be addressed for it to perform them successfully. For example, the WHO plays a unique and irreplaceable role in providing certain global public goods and in fulfilling most elements of the stewardship function. This core work must be protected and strengthened in any reform of the institution. Focusing on strong stewardship would also help to address the sectoral challenge, especially by developing stronger competencies in the WHO and other agencies for cross-sectoral health advocacy.

These governance challenges are not new. The past decade has shown that the health arena can be fertile ground for institutional innovation. For example, there have been attempts to strengthen accountability and legitimacy by according formal decision-making roles to a broader range of actors; the governing boards of the GAVI Alliance, UNITAID, and the Global Fund to Fight AIDS, Tuberculosis, and Malaria include nonstate representatives, such as civil society organizations, communities of people affected by target diseases, and foundations, reflecting an attempt at more inclusive governance. Furthermore, global norms on intellectual property have evolved to become more sensitive to concerns about access to medicines as health advocates have gained some influence in trade policymaking. ${ }^{50}$

However, these encouraging innovations remain limited to a handful of institutions and are largely in their infancy. The global health system is still hamstrung by the structural governance challenges presented here. Innovative global governance arrangements should continue to be tested, evaluated, improved, and - where successful - replicated. Rigorous research and analysis of the achievements and shortfalls of past experiments in governance arrangements are needed and merit greater attention from the academic community. Leaders of governments, multilateral institutions, civil society organizations, firms, foundations, and other influential actors should identify new governance arrangements that are more effective, equitable, and accountable.

Governance challenges will continue to complicate our best efforts to respond to urgent, complex, and serious global health problems. Any effort to strengthen the global health system will require recognition and management of these tensions so that the system can better face the realities of interdependence in the 21st century.

Disclosure forms provided by the authors are available with the full text of this article at NEJM.org.
REFERENCES

1. Frenk J, Gómez-Dantés O, Chacón F. Global health in transition. In: Parker RG, Sommer M, eds. Routledge handbook of global public health. New York: Routledge, 2011:11-7.

2. Frenk J, Sepúlveda J, Gómez-Dantés O, McGuiness MJ, Knaul F. The New
World order and international health. BMJ 1997;314:1404-7.

3. Keohane RO, Nye JS. Interdependence in world politics. In: Crane GT, Amawi A, eds. The theoretical evolution of international political economy: a reader. New York: Oxford University Press, 1997:122-32.
4. Chen L, Bell D, Bates L. World health and institutional change. In: Pocantico Retreat - enhancing the performance of international health institutions. Cambridge, MA: The Rockefeller Foundation, Social Science Research Council, Harvard School of Public Health, 1996:9-21. 
5. United Nations Development Programme (UNDP). Governance for sustainable human development. New York: UNDP, 1997.

6. Weiss TG. Governance, good governance and global governance: conceptual and actual challenges. Third World Q 2000;21:795-814.

7. Finkelstein LS. What is global governance? Global Governance 1995;1:367-72. 8. Commission on Global Governance. Our global neighbourhood. Oxford, United Kingdom: Oxford University Press, 1995.

9. Szlezák NA, Bloom BR, Jamison DT, et al. The global health system: actors, norms, and expectations in transition. PLoS Med 2010;7(1):e1000183.

10. The NIH almanac: appropriations 2011. Rockville, MD: National Institutes of Health (http://www.nih.gov/about/ almanac/appropriations/part2.htm).

11. Congressional budget justification volume 2: foreign operations fiscal year 2011. Washington, DC: Department of State, 2011.

12. Provost C. The future of UK aid 2010 2015 - get the data. The Guardian. October 5, 2011 (http://www.guardian.co.uk/ global-development/datablog/2011/ oct/05/datablog-future-plans-uk-aid). 13. Norwegian aid statistics. Oslo: Norwegian Agency for Development Cooperation (Norad), 2011 (http://www.norad.no/en/ tools-and-publications/norwegian-aidstatistics).

14. Unaudited interim financial report for the year 2010: financial period 20102011 (report A64/29). Geneva: World Health Organization, 2011.

15. United Nations Children's Fund (UNICEF). Annual report 2010. New York: UNICEF, 2011 (http://www.unicef.org/ publications/index_58840.html).

16. United Nations Population Fund (UNFPA). Annual report 2010. New York: UNFPA, 2011 (http://unfpa.org/public/ home/publications/pid/7797).

17. Joint United Nations Programme on HIV/AIDS (UNAIDS). Annual report 2009. Geneva: UNAIDS, 2010 (http://data .unaids.org/pub/Report/2010/2009 annual_report_en.pdf).

18. The World Bank. The World Bank annual report 2011. Washington, DC: World Bank, 2011.

19. Bernescut B, Grubb I, Jurgens R, Hacopian P. The Global Fund annual report 2010. Geneva: The Global Fund to Fight AIDS, Tuberculosis and Malaria, 2011 (http://www.theglobalfund.org/en/ library/publications/annualreports).

20. Global Alliance for Vaccines and Immunization (GAVI). GAVI Alliance annual financial report 2010. Geneva: The GAVI Alliance, 2011.

21. UNITAID annual report 2010. Geneva: World Health Organization, Secretariat of UNITAID, 2011 (http://www.unitaid
.eu/images/NewWeb/documents/AR10/ unitaid_ar2010_web.pdf)

22. Bill \& Melinda Gates Foundation 2010 annual report. Seattle: Bill \& Melind Gates Foundation, 2011 (http://www .gatesfoundation.org/annualreport/2010/ Pages/overview.aspx).

23. The Rockefeller Foundation 2009 annual report. New York: The Rockefeller Foundation, 2010 (http://2009annualreport .rockefellerfoundation.org).

24. Wellcome Trust annual report and financial statements 2010. London: Wellcome Trust, 2011 (http://www.wellcome .ac.uk/stellent/groups/corporatesite/ @msh_publishing_group/documents/ web_document/wtx063982.pdf).

25. Médecins Sans Frontières (MSF) activity report 2010. Geneva: Médecins Sans Frontières (MSF), 2011 (http://www .doctorswithoutborders.org/publications/ ar/report.cfm?id=5457\&cat=activityreport).

26. Oxfam International annual report 2010-2011. Oxford, United Kingdom: Oxfam, 2011 (http://www.oxfam.org/sites www.oxfam.org/files/oxfam-annualreport-2010-11.pdf).

27. CARE International annual report 2010. Geneva: CARE International, 2011 (http://www.care-international.org/ Media-Releases/care-launches-2010annual-report.html)

28. IMS Institute for Healthcare Informatics. Global use of medicines: outlook through 2015. IMS Health, 2011 (http:// www.imshealth.com/deployedfiles/ims/ Global/Content/Insights/IMS\%20Institute $\% 20$ for\%20Healthcare\%20Informatics/

Global_Use_of_Medicines_Report.pdf).

29. Frenk J, Chen L, Bhutta ZA, et al Health professionals for a new century: transforming education to strengthen health systems in an interdependent world. Lancet 2010;376:1923-58.

30. McColl K. Europe told to deliver more aid for health. Lancet 2008;371:2072-3.

31. Costello A, Abbas M, Allen A, et al Managing the health effects of climate change: Lancet and University College London Institute for Global Health Commission. Lancet 2009;373:1693-733. [Erratum, Lancet 2009;373:2200.]

32. Lee K, Sridhar D, Patel M. Bridging the divide: global governance of trade and health. Lancet 2009;373:416-22.

33. Smith RD, Correa C, Oh C. Trade, TRIPS, and pharmaceuticals. Lancet 2009;373:684-91.

34. Moon S, Szlezák NA, Michaud C, et al The global health system: lessons for a stronger institutional framework. PLoS Med 2010;7(1):e1000193.

35. Lee K, Fidler D. Avian and pandemic influenza: progress and problems with global health governance. Glob Public Health 2007;2:215-34.

36. Fidler D. Architecture amidst anarchy: global health's quest for governance. Global Health Governance 2007;1:1-17.

37. Fidler D. The challenges of global health governance. New York: Council on Foreign Relations, 2010.

38. Bloom BR. WHO needs change. Nature 2011;473:143-5.

39. Ottersen OP, Frenk J, Horton R. The Lancet-University of Oslo Commission on Global Governance for Health, in collaboration with the Harvard Global Health Institute. Lancet 2011;378:1612-3. 40. Jamison DT, Frenk J, Knaul F. International collective action in health: objectives, functions and rationale. Lancet 1998;351:514-7.

41. Kickbusch I, Gleicher D. Governance for health in the 21st century: a study conducted for the WHO Regional Office for Europe. Copenhagen: World Health Organization Regional Office for Europe, 2011. 42. Commission on Social Determinants of Health. Closing the gap in a generation: health equity through action on the social determinants of health: final report of the Commission on Social Determinants of Health. Geneva: World Health Organization, 2008.

43. WHO Consultative Expert Working Group on Research and Development (CEWG). Research and development to meet health needs in developing countries: strengthening global financing and coordination. Geneva: World Health Organization, 2012.

44. Stiglitz J. Knowledge as a global public good. In: Kaul I, Grunberg I, Stern MA, eds. Global public goods: international cooperation in the 21st century. Oxford, United Kingdom: Oxford University Press, 1999:308-25.

45. Barrett S. Why cooperate? The incentive to supply global public goods. Oxford, United Kingdom: Oxford University Press, 2007.

46. Moon S, Bermudez J, 't Hoen E. Innovation and access to medicines for neglected populations: could a treaty address a broken pharmaceutical R\&D system? PLoS Med 2012;9(5):e1001218.

47. Durkheim E. The division of labor in society. Glencoe, IL: Free Press, 1964.

48. Murray CJ, Frenk J. A framework for assessing the performance of health systems. Bull World Health Organ 2000;78: 717-31.

49. Leach-Kemon K, Chou DP, Schneider MP, et al. The global financial crisis has led to a slowdown in growth of funding to improve health in many developing countries. Health Aff (Millwood) 2012; 31:228-35.

50. Moon S. Embedding neoliberalism: global health and the evolution of the global intellectual property regime (1994-2009). (Ph.D. dissertation. Cambridge, MA: Harvard University, 2010.)

Copyright (c) 2013 Massachusetts Medical Society. 